\title{
Potential of NanoPro to reduce fungicide rate for control of Microdochium nivale on an annual bluegrass (Poa annua) green
}

\author{
Tatsiana Espevig $^{1, *}$, Trond O. Pettersen ${ }^{1}$, and Trygve S. Aamlid ${ }^{1}$ \\ ${ }^{1}$ NIBIO - Norwegian Institute of Bioeconomy Research, Department Urban Greening and Vegetation \\ Ecology, 4886 Grimstad, Norway
}

\begin{abstract}
This is a report on the potential of NanoPro ${ }^{\mathrm{TM}}$ to reduce the rate of two commonly used fungicides for control of Microdochium patch (Microdochium nivale), the economically most important turfgrass disease in Scandinavia. The experiment was conducted from 14 Sept. 2018 to 1 May 2019 on an annual bluegrass golf green at the NIBIO Turfgrass Research Center Landvik. Use of NanoPro ${ }^{\mathrm{TM}}$ at a rate of $292 \mathrm{ml} / \mathrm{ha}$ in tank mixture with the systemic fungicide Delaro ${ }^{\circledR}$ SC 325 or/and the contact fungicide Medallion ${ }^{\circledR}$ TL produced the same level of disease control with a $30-60 \%$ reduction in fungicide dosage as with full fungicide dosage without additive. NanoPro ${ }^{\mathrm{TM}}$ was more effective with Medallion ${ }^{\circledR}$ TL than with Delaro ${ }^{\circledR}$ SC 325 . We conclude that NanoPro ${ }^{\mathrm{TM}}$ may have a big potential in Scandinavia and other countries where authorities require reduced fungicide use. The experiment should be repeated one more year before giving final recommendations.
\end{abstract}

\section{Introduction}

Microdochium patch is the economically most important disease in turfgrass in Scandinavia. On golf greens with susceptible species and winter conditions favourable for snow moulds the damage from Microdochium patch can be up to $100 \%$ [1]. Thus, the use of systemic and contact fungicides in fall is necessary to protect golf greens from severe snow mould damage.

According to IPM (integrated pest management) principles, fungicide use should be sustainable. The use of fungicides can be significantly reduced by adding substances, which by themselves have no fungicidal properties but improve fungicide efficacy. NanoPro ${ }^{\mathrm{TM}}$ is an additive produced by Aqua-Yield, Salt Lake City, USA. NanoPro ${ }^{\mathrm{TM}}$ contains $99 \%$ water and $1 \%$ humic acid derived from Leonardite as the active ingredient. Humates are natural organic substances, high in humic acids and often containing trace minerals necessary for plants [2]. Humates are an important soil component also because they constitute a stable fraction of carbon and improve water holding capacity and $\mathrm{pH}$ buffering [3]. Benefits of humic acids as additives to liquid fertilizer for foliar feeding and also to improve root uptake of fertilizers applied to soils are widely recognised in agriculture. Reports on the

\footnotetext{
* Corresponding author: tatsiana.espevig@nibio.no
} 
application of humic acids to turfgrasses as a part of a fertilization program or for disease control are, however, scarce $[4,5]$. To the best of our knowledge, there are no reports on use of humic acid as additives to fungicides for Microdochium patch control on golf greens.

The objective of our study was to investigate the potential for NanoPro ${ }^{\mathrm{TM}}$ to reduce the rate of two commonly used fungicides for control of Microdochium patch in Scandinavia.

\section{Materials and methods}

\subsection{Experimental site and general maintenance}

The experiment was conducted from 14 Sept. 2018 to 1 May 2019 on a newly established annual bluegrass (Poa annua L.) golf green at the NIBIO Turfgrass Research Centre Landvik, Grimstad, SE Norway (58 $34^{\prime} \mathrm{N}, 8^{\circ} 52^{\prime} \mathrm{E}, 10 \mathrm{~m}$ a.s.1.). The root zone of the green was constructed according to USGA-specifications [6] and consisted of $88 \%$ sand and $12 \%$ Sphagnum peat (v/v). In July-October, the green was mowed three times per week to $5 \mathrm{~mm}$ using a single walk-behind green's mower and top-dressed weekly for a total height of 5 $\mathrm{mm}$ sand. The green was fertilized from 31 May to 7 November using either Wallco liquid fertilizer 5-1-4 (Orkla Care, Solna, Sweden) Greenmaster zero 14-0-10 (ICL Speciality Fertilizers, Ipswich, UK). The total NPK amounted to $293 \mathrm{~kg} \mathrm{~N}, 56 \mathrm{~kg} \mathrm{P}$ and $200 \mathrm{~kg} \mathrm{~K} \mathrm{ha}^{-1}$ (including the first pre-seeding application with the organic fertilizer Marihøne Pluss 8-2-5, Norsk Naturgjødsel, Voll, Norway). In the spring 2019 the green was fertilized twice in April with a total of $32 \mathrm{~kg} \mathrm{~N}, 4 \mathrm{~kg} \mathrm{P}$ and $23 \mathrm{~kg} \mathrm{~K} \mathrm{ha}^{-1}$. The green was irrigated with $5 \mathrm{~mm}$ water after fertilization and/or topdressing and to field capacity each time the average volumetric soil water content in the $12 \mathrm{~cm}$ top layer dropped below $12 \%(\mathrm{v} / \mathrm{v})$ as measured with a TDR meter (Field Scout 300; Spectrum Technologies, Aurora, Illinois, USA).

\subsection{Experimental plan and implementation}

The experiment was laid out according to a one-factorial randomised complete block design with 4 replicates per treatment. Individual plot size was $3 \mathrm{~m}^{2}(2.0 \times 1.5 \mathrm{~m})$ of which the registration plot area was $1.5 \mathrm{~m}^{2}(1.0 \times 1.5 \mathrm{~m})$ to avoid border effects. Delaro ${ }^{\circ} \mathrm{SC} 325$ (trifloxystrobin $150 \mathrm{~g} \mathrm{~L}^{-1}$ and protioconazole $175 \mathrm{~g} \mathrm{~L}^{-1}$ ), a 'systemic' fungicide from Bayer Crop Science (Leverkusen, Germany) was applied on 19 Sept. 2018, while Medallion ${ }^{\circledR}$ TL (fludioxonil $125 \mathrm{~g} \mathrm{~L}^{-1}$ ), a 'contact' fungicide from Syngenta (Basel, Switzerland) was applied on 15 Nov 2018. Delaro and Medallion were applied at their recommended rates (1.0 $\mathrm{L} \mathrm{ha}^{-1}$ and $3 \mathrm{~L} \mathrm{ha}^{-1}$, respectively) and at $70 \%$ and $40 \%$ of their recommended dosage rates with and without NanoPro ${ }^{\mathrm{TM}}\left(292 \mathrm{ml} \mathrm{ha}^{-1}\right)$ in the tank mixture. The fungicides (with or without NanoPro ${ }^{\mathrm{TM}}$ ) were applied in a water volume of $250 \mathrm{~L} \mathrm{ha}^{-1}$ using an experimental backpack plot sprayer (Oxford/LTI) working at 150-200 kPa pressure. The spraying boom had three nozzles spaced $50 \mathrm{~cm}$ apart and screens on both sides that prevented drift to neighbour plots and secured that the boom was always $50 \mathrm{~cm}$ above the canopy. The actual application rates were recorded by weighing the tank before and after spraying and they were within $\pm 10 \%$ limit set by the Norwegian Good Experimental Practice (GEP) Standard.

\subsection{Registrations, weather data and statistical analysis}

The incidence of Microdochium patch, caused by Microdochium nivale, was registered as percentage of plot area covered with diseased turf. The assessments started on 19 Sept. and were done at 2-wk interval to 27 Nov. and then on 2 Jan., 26 Feb., 20 March and 23 April. 
The disease intensity was expressed by the area under disease progress curve (AUDPC) which was calculated by multiplying the average Microdochium patch incidence on two subsequent observations by the time (days) between these observations from 19 Sept. to 23 April and taking the sum of all these multiplied numbers. Tiller density was assessed visually using a scale from 1 (very thin) to 9 (very dense). Turf quality was assessed using a scale from 1 (poor and uneven turf) to 9 (even and very good turf), with 5 as the lowest value for acceptable turf quality.

Weather data were obtained from the local weather station (Landbruksmeteorologisk Tjeneste, https://mt.nibio.no/agrometbase/getweatherdata_new.php). All months from September 2018 through April 2019 had on average $2{ }^{\circ} \mathrm{C}$ higher monthly temperatures than the 30 -yr average of $3{ }^{\circ} \mathrm{C}$. The total amount of precipitation $106 \mathrm{~mm}$ in October 2018 was below than the climic norm $162 \mathrm{~mm}$. But the total precipitations in September, November and December 2018 were 78, 53 and $113 \mathrm{~mm}$ higher than normal of 136, 143 and $102 \mathrm{~mm}$, respectively. The snow cover events lasted from 2 days to two weeks from November 2018 to February 2019 with total duration of 39 days.

The data were analysed using the SAS procedure PROC ANOVA for a one-factorial randomized complete design with 4 blocks. The Fisher's least significant difference (LSD) was used to separate mean values at the $\mathrm{p}<0.05$ probability.

\section{Results and discussion}

The first sign of Microdochium patch appeared in early September 2018. A significant increase in the disease started in late October (data not shown). The development of Microdochium patch during the winter resulted in $64 \%$ disease intensity on unsprayed plots on 20 March 2019. After this, the diseases started to decline and on 23 April (the last registration in the experiment) it amounted to $55 \%$ of plot area.

The area under disease progress curve (AUDPC) which describes and gives a quantitative summary of disease intensity from 19 Sept. 2018 to 20 March 2019, showed a significant effect of NanoPro ${ }^{\mathrm{TM}}$ at $40 \%$ fungicide rate (Table 1) and clear trend also at $70 \%$ fungicide rate. When applied without $\mathrm{NanoPro}^{\mathrm{TM}}, 100 \%, 70 \%$ and $40 \%$ rate of Delaro plus Medalion reduced Microdochium patch by $94 \%, 82 \%$ and only $31 \%$, respectively, as compared with unsprayed plots. NanoPro ${ }^{\mathrm{TM}}$ in tank mixture with $70 \%$ fungicide dosage rate led to $11 \%$ and $15 \%$ higher Microdochium patch reduction when used with Delaro and Medallion, respectively, but differences were not significant. When tank-mixed with $40 \%$ rates of Delaro, Medallion and both fungicides, NanoPro ${ }^{\mathrm{TM}}$ resulted in 36\%, 56\% and 55\% higher microdochium patch reductions than the $40 \%$ fungicide rate used alone. Moreover, the use of NanoPro ${ }^{\mathrm{TM}}$ with $40 \%$ fungicide rate resulted in an equally good microdochium patch control (reduction) as the $100 \%$ (recommended) fungicide rate. We also found that the additive effect of NanoPro ${ }^{\mathrm{TM}}$ was more pronounced when added to Medallion than when added to Delaro at $40 \%$ fungicide rate.

The shoot density on all plots was 7.5 in September-November (data not shown). On 23 April, the lowest density of 6.8 was recorded on unsprayed plots, not significantly different from plots with $70 \%$ and $40 \%$ fungicide dosage rates without $\operatorname{NanoPro}^{\mathrm{TM}}$ (Table 1). NanoPro ${ }^{\mathrm{TM}}$ improved density by 0.6 units on average for all plots which received the additive as compared with unsprayed plots.

By the start of the experiment on 19 September the turf quality scored 7 on average for all plots (Figure 1). From 2 October the turf quality was obviously lower on the plots with the higher amount of microdochium patch and it was negatively correlated with amount of disease $(\mathrm{r}=-0.9)$. Based on the criterion that 5.0 is the lowest score for acceptable turf, the turf became unacceptable from $12^{\text {th }}$ of November onwards in the unsprayed control 
treatment and in treatments sprayed with $40 \%$ fungicide dosage rate, but remained acceptable until January if NanoPro ${ }^{\mathrm{TM}}$ was added to the $40 \%$ rate of Delaro. The five other treatments maintained acceptable turf quality throughout the experiment and had an average score of 5.7 by the end of the experiment on 23 April.

Table 1. Effect of NanoPro ${ }^{\mathrm{TM}}$ on area under disease progress curve (AUDPC) from 19 Sept. 2018 to 20 March 2019 and on shoot density of annual bluegrass on 23 April 2019.

\begin{tabular}{|c|c|c|c|c|}
\hline \multicolumn{3}{|c|}{ Treatments } & \multirow[b]{2}{*}{$\begin{array}{l}\text { Microdochium } \\
\text { patch, AUDPC }\end{array}$} & \multirow[b]{2}{*}{$\begin{array}{l}\text { Shoot density } \\
23 \text { Apr. } 2019\end{array}$} \\
\hline $\mathrm{Nr}$. & $\begin{array}{l}\text { Delaro, } \\
\% \text { of reccom. rate }\end{array}$ & $\begin{array}{l}\text { Medallion, } \\
\% \text { of reccom. rate }\end{array}$ & & \\
\hline 1 & 0 (control) & 0 (control) & $906 \mathrm{a}$ & $6.8 \mathrm{~b}$ \\
\hline 2 & 100 & 100 & $54 \mathrm{c}$ & $7.4 \mathrm{a}$ \\
\hline 3 & 70 & 70 & $166 \mathrm{bc}$ & $7.1 \mathrm{ab}$ \\
\hline 4 & 70+NanoPro ${ }^{\mathrm{TM}}$ & 70 & $62 \mathrm{c}$ & $7.3 \mathrm{a}$ \\
\hline 5 & 70 & 70+NanoPro ${ }^{\mathrm{TM}}$ & $29 \mathrm{c}$ & $7.5 \mathrm{a}$ \\
\hline 6 & 40 & 40 & $630 \mathrm{ab}$ & $7.1 \mathrm{ab}$ \\
\hline 7 & 40+NanoPro ${ }^{\mathrm{TM}}$ & 40 & $301 \mathrm{bc}$ & $7.3 \mathrm{a}$ \\
\hline 8 & 40 & 40+NanoPro ${ }^{\mathrm{TM}}$ & $119 \mathrm{c}$ & $7.4 \mathrm{a}$ \\
\hline \multirow[t]{2}{*}{9} & 40+NanoPro ${ }^{\mathrm{TM}}$ & $40+\mathrm{NanoPro}^{\mathrm{TM}}$ & $123 \mathrm{c}$ & $7.4 \mathrm{a}$ \\
\hline & $p$ & & $*$ & $*$ \\
\hline
\end{tabular}

* - significant differences among the treatments at $p<0.05$. The same letter indicate no difference among the means based on Fisher protected LSD test $(\alpha=0.05)$.

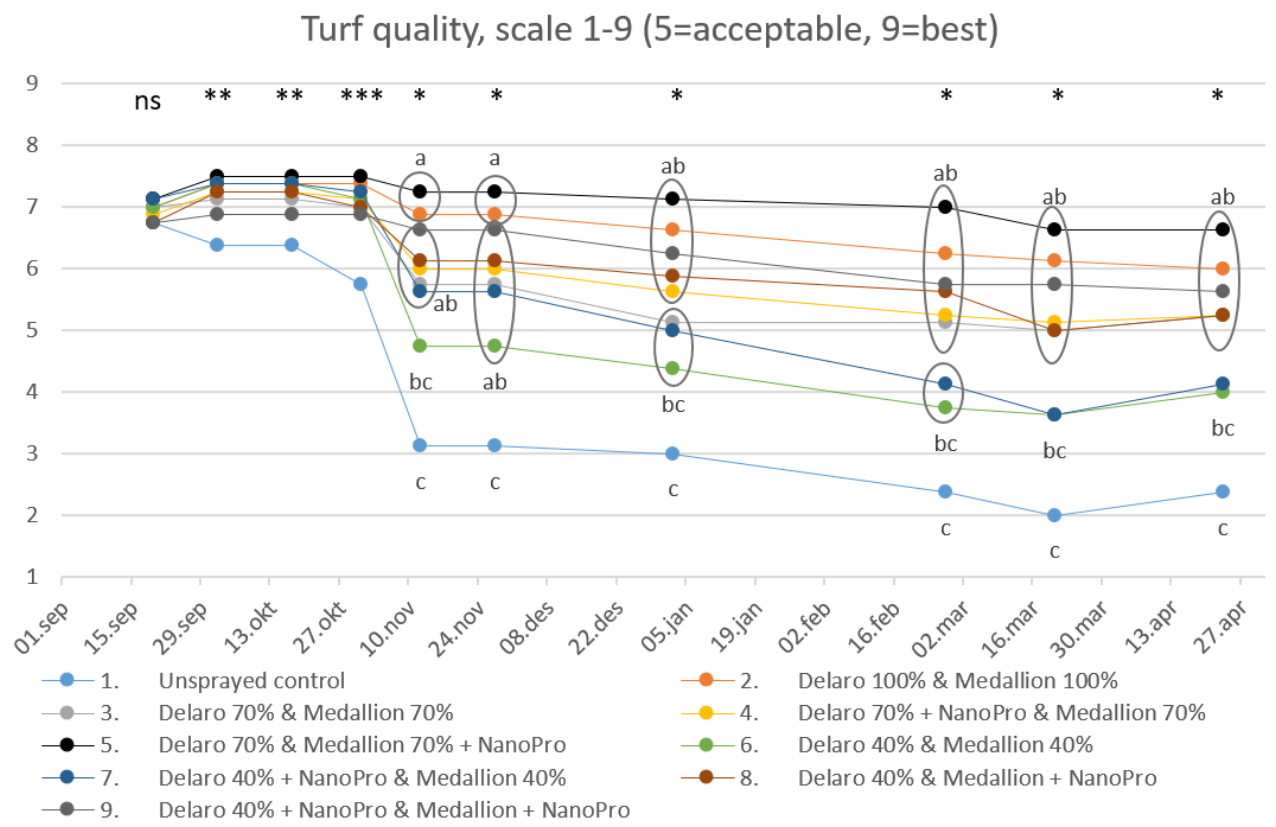

Figure 1. Effect of NanoPro ${ }^{\mathrm{TM}}$ used as additive to the fungicides on turf quality of annual bluegrass green. The stars indicate significant differences among the treatments : ${ }^{*}$ significant at $\mathrm{p}<0.05, * *$ significant at $\mathrm{p}<0.01, * * *$ significant at $\mathrm{p}<0.001$, and ns when non-significant. The same letter indicates no significant difference among the treatments on the same date at $\mathrm{p}<0.05$ based on Fisher LSD. 


\section{Conclusions}

Use of NanoPro ${ }^{\mathrm{TM}}$ at a rate of $292 \mathrm{ml} \mathrm{ha}^{-1}$ in tank mixture with the systemic fungicide Delaro or/and the contact fungicide Medallion on an annual bluegrass golf green confirmed its potential to produce the same level of disease control with a 30-60\% reduction in fungicide rate as with full fungicide rate without additive. It appears that NanoPro ${ }^{\mathrm{TM}}$ 's additive effect was more pronounced with Medallion than with Delaro.

According to IPM principles, Scandinavian authorities currently have a strong focus on how to reduce pesticide use in green amenity areas. Restrictions on the total use of fungicides have been introduced in all Scandinavian countries. In this context NanoPro ${ }^{\text {TM }}$ and other low-risk additives may have a big potential in Scandinavia and elsewhere. The experiment ought to be repeated for one more year before final recommendations can be given.

\section{Acknowledgements}

This study was funded by Østfold Gress AS. We thank Borregaard GC in Sarpsborg (Norway) for providing of annual bluegrass plugs for establishment of the field trial.

\section{References}

1. A. Kvalbein, W.M. Waalen, L. Bjørnstad, T.S. Aamlid, T. Espevig, Int. Turfgrass Soc. Res. J. 13, 604-609 (2017).

2. T.L. Senn, Humates in Agriculture (Acres USA, Jan (1991).

3. R. McDonnell, N.M. Holden, S.M. Ward, J.F. Collins, E.P. Farrell, M.H.B. Hayes, Biol. Environ. 101, 187-197 (2001).

4. X. Zhang, E.H. Ervin, R.E. Schmidt, J. Amer. Soc. Hort. Sci. 128, 492-496 (2003).

5. J.E. Kaminski, P.H. Dernoeden, C.A. Bigelow, HortSci. 39, 620-626 (2004).

6. USGA Green Section Staff, http://archive.lib.msu.edu/tic/usgamisc/monos/2018recommendationsmethodputtinggre en.pdf (Accessed on 13 Nov. 2019) 